\title{
COMPENSATION OF WORK INJURIES AND OCCUPATIONAL DISEASES - A COMPARATIVE APPROACH
}

\begin{abstract}
The risk of work injury, as well as the risk of occupational disease, now traditionally, have preferential treatment when it comes to the matter of compensation - which has not always been the case and which is being challenged by some even nowadays. The aim of this research is to present an overview of different systems of compensation when it comes to these risks, as well as to give an idea of their positive and negative characteristics. This due to the fact that it is a matter of great importance for the employees and for the employers alike. The conclusion is that it is not easy to form a decisive stand on which of the elaborated systems is better, as they all have advantages and disadvantages. Nevertheless, the state in questionthat is its legislature, should make balance of interests of employees and employers its main goal while addressing this matter in order for social peace and social justice to be acquired.

Keywords: work injury, occupational disease, compensation, workers' compensation system, employers' liability system.
\end{abstract}

\section{General observations}

In the feudal period no one would have regarded the risk of accidental injury or death at work as other than part of the ordinary risk of existence itself (Hendy, 2006, pp. 2-3). Things got even worse with the beginning of the industrial revolution and the application of the laissez faire politics which excluded the possibility of state intervention when it came to labour relations (Ravnić, 2004, p. 335). Namely, this meant that the lawmaker could not intervene when it came to the matter of social security in order to protect the victims of risks related to work up until the end of the nineteenth century. Therefore, since the freedom of entrepreneurship and ruthless competition of the time could not recognize solidarity and humanity as a virtue, this led to them being only possible virtues of rare individuals (Lubarda, 2013, pp. 475-476).

Consequently, the protection of social risks themselves was, in the beginning, secured within the family, or on the basis of some other forms of private assistance, savings, insurance and civil liability, which had proved to be inefficient and insufficient.

* MA, PhD candidate at Faculty of Law, University of Belgrade, Serbia, e-mail: mila.petrovic89@gmail.com. 
Civil liability itself, for example, was not good enough of a solution due to the fact that the employee had to prove the fault of the employer for the damage caused by the accident at work (Kovačević, 2007, pp. 71-78). Namely, the fault of the employer was almost impossible to be proved and the reason for dissatisfaction was that employers were quite successful in avoiding liability in the nineteenth century. This was due to the doctrines of contributory negligence, assumption of risk as well as the fellow servant rule (Glynn, 2016, p. 92 ) - the so called "unholy" trinity od defences (Wagner, 2012, p. 12). With that being said, it was clear to see that this type of protection would almost certainly leave the employees uncompensated.

Since the labour force was abundant and there were hardly any protective regulations, the employees had to struggle with difficult working conditions and poor safety and health at work which had resulted in numerous accidents at work (many of which were fatal). Such treatment of workers was not in accordance with the idea of social justice, which led to adoptions of laws that dealt with the matter of protection of workers from accidents at work (Kovačević, 2007, pp. 71-79). Therefore, at the end of the nineteenth century mandatory state organized social insurance for industrial injuries was introduced, with Germany as a pioneer - that is as the first country that has established it in the year of 1884 (Hoop, 2007, pp. 93-94).

In this paper we will present different types of systems designed for the purpose of compensating the risks of work injuries and occupational diseases, with in detail description of their notable characteristics. The named description is needed in order to form the idea not only about those systems themselves, but also to form an understanding of the way that they function, as well as to comprehend the aftermath of their application.

\section{Possible forms of compensation of work injuries and occupational diseases}

Work injuries and occupational diseases nowadays traditionally enjoy preferential treatment comparing to injuries and diseases that are not caused by work. Reasons for this kind of preferential treatment may vary from: the high value which society places on work; the fact that employees are obliged to obey their employers and that employers have full control over the working conditions and matters of safety, to the need to provide an incentive for the people who carry out dangerous but essential work. On the other hand, we also encounter a different opinion of the mentioned status of these risks, which is that this kind of preferential treatment ("industrial preference") is unwarranted due to the fact that financial needs created by bodily injuries and diseases are the same for everyone. This also leads to a conclusion that the general system of social security should be designed accordingly, treating every citizen equally and making the level of benefits contingent on needs only (Wagner, 2012, pp. 34-35). Adding on - some authors state that this preference at first actually took place only due to powerful political arguments and the desire to comply with the demands of the trade unions (Parsons, 2002, p. 360; Lewis, 2012, p. 142). Therefore in countries such as the United Kingdom (UK) and the Netherlands the only thing that matters is the severity of the injury or disease and the 
demand for medical treatment or income replacement created by it, regardless of the cause of the disease or the injury (Wagner, 2012, p. 35). In that sense it should be noted that national work injury compensation systems may vary from employers' liability systems to workers' compensation systems - although the two of them (in most cases) exist at the same time, function mutually and supplement each other. It should also be noted that in countries where workers' compensation system does exist, the additional right to sue the employer varies from country to country (Kun, 2014, p. 66). And while in countries such as Germany the workers' compensation system still stands strong, in the Netherlands workers' compensation system is essentially replaced with a combination of social security benefits and supplementary employers' liability (Wagner, 2012, p. 36). Namely, this happened due to an obvious trend (which also took place in the UK) of a reorientation of national no fault compensation systems towards employers' civil law based liability (Kun, 2014. p. 67). But, in our opinion, it also seems to have a lot to do with the approach to the treatment of work injuries and occupational diseases. Anyhow, it should be known that no European country has gone that far as to deprive injured employees from any sort of compensation in the absence of fault or breach of the legal duty on the part of the employer, and to apply the employers' liability as an exclusive remedy (Parsons, 2002, p. 363).

Regardless of the type of scheme that is applied in one country (that is whether a workers' compensation system or employers' liability system was introduced), there are three main functions that they are to perform. Those functions are the support of prevention, assistance in the rehabilitation process and, finally, compensation to the individual workers - the so-called holistic approach (ILO, 2013, pp. 1, 15).

\subsection{Workers' compensation system}

Workers' compensation for damage from work injuries and occupational diseases is a specific form of social security which is - in most countries, included in national social security systems. Work accident insurance itself usually is a separate component of the social security system, but in some countries it is completely integrated into the overall social security system (Kun, 2014, pp. 66-67). Some of the examples for the latter are the Republic of Serbia, as well as Hungary (Kun, 2014, p. 67) and Greece (Kremalis, 2015, p. 114). This system can also be viewed as an underdeveloped type of workers' compensation system since it doesn't recognize the application of a specific, independent insurance scheme against accidents at work and occupational disease (Kun, 2014, p. 70).

Some of the basic features of workers' compensation systems are the fact that workers are entitled to compensation regardless of fault on the part of the employer, limited compensation and immunity of employers from damages suits, (Wagner, 2012, pp. 5-10) while, as pointed out by Kun (2014, p. 69), the perceived advantages of such systems are their automatic, speedy, transparent and fair results in recompensation.

As already stated - the entitlement to compensation of work injuries and occupational diseases within workers' compensation systems exists regardless of fault on the part of the employer which in other words means that workers' compensation systems 
are based on the principle of strict liability. In practice this actually means that the party that is strictly liable is not the employer himself but rather the public insurance carrier, although - since the employer is the one that bears the costs of financing of such a system, he remains strictly liable (Wagner, 2012, pp. 5-6). This due to the fact the employers' liability is based on liability for the risque professionnel, which essentially means that the risk of engaging in some kind of economic activity represents the basic criteria for the right to a damage claim against the employer (Kovačević, 2007, p. 79), that is, as we could see, the insurance carrier in this case. The liability comes from the "hazardous item" or from the "hazardous activity" itself, which means that it is the item or the activity itself that inevitably comes along with danger (Ravnić, 2004, p. 370).

The second aforementioned characteristic of workers' compensation systems means that the amounts paid out from compensation systems are standardised and therefore limited, which is the reason why it is possible for a parallel, supplementary role of the employers' civil law based liability to exist (Kun, 2014, p. 67). One can wonder, on the other hand, whether this side of workers' compensation systems is questioning the existence of before mentioned fair results in compensation - which are perceived to be their advantage. In that sense it can also be claimed that „workers' compensation systems are based on an implicit bargain in which the worker eschews full compensation of any loss sustained in exchange for no-fault liability of a public insurance carrier" (Wagner, 2012, p. 50). This brings us to the third characteristics of workers' compensation systems which is the immunity of the employer.

The reason for the immunity of employers for damages suits lies in the fact that the employers are the ones who bear the costs of funding of such systems, which is why the costs of the individual claims brought against them would basically double their costs. That would - as a result, force the employees to accept lower wages. On the other hand, this doesn't mean that this immunity is absolute, which is why it doesn't apply if the employer intentionally caused the harm (Wagner, 2012, pp. 10, 46). In that sense, Parsons (2002, p. 363) notices that „strict employers' liability is somewhat anomalous in a system where no-fault workers' compensation benefits are also available". On the other hand, in some countries (Republic of Serbia being one of them) such immunity does not exist. Therefore, in the Republic of Serbia for example, the employer can be held liable for the occurrence of work injury or occupational disease (Labour Law, 2005, art. 164) on the basis of strict liability as well as on the basis of fault liability (Law of Contracts and Torts, 1978, art. 97, 161-163, 173-177). But one should have in mind here that in the Republic of Serbia contributions for these risks are being paid both by employers and employees. Namely, in the Republic of Serbia earmarked accounts do not exist, whilst the workers' compensation system is financed not only by employers, but also by employees (Law on Contributions for Compulsory Social Insurance, 2004, art. 7-12). Similar approach can, for example, also be found in Greece (MISSOC database, n.d). On the other hand, the fact that the workers' compensation system itself is not solely financed by employers does not necessarily have to be perceived as an insuperable obstacle for a different solution in that sense. Therefore it should be noted that in Greece, according to the previous regulations, the employer had no obligation when it came to the compensation of work injuries and occupational diseases of the affected employee - 
unless the accident was the result of the employer's wilful misconduct or wilful misconduct of his representatives in the workplace (Douka \& Koniaris, 2015, p. 173). The reason for this was the obligation of the employer to pay an additional insurance contribution of $1 \%$ of the total wages to the Social Insurance Institute (IKA) (Dontas, 2017). However, when it comes to workers' compensation, government will, as a rule, try to separate its accounts from the general budget and revenue systems, which is basically done by establishing earmarked accounts. The goal of the above-mentioned approach is to have the employers fund these separate programs (Klein \& Krohm, 2006, p. 2).

The named immunity of employers has actually led to some interesting consequences in some countries. The best example for this would be the case of the United States of the America (USA). Namely, In the USA the limitation of the right to a tort suit when the worker is covered by the workers' compensation system goes as far as to the sole remedy for workplace injuries being workers compensation' system benefits, unless the employer intentionally hurt the worker. This has led to a common politics of tort lawsuits against third parties such as manufacturers (Glynn, 2016, p. 94). On the other hand, in Germany the immunity of employers is also established when it comes to cases of non-pecuniary loses, which, as such, are not covered by the workers' compensation system. This is why such an exclusion of damages for non-pecuniary loses from the benefits offered by the workers' compensation system has been challenged in front of the Federal Constitutional Court more than once (Wagner, 2012, pp. 49-50). This also brings us to another characteristic of workers' compensation systems that was not mentioned before, and that is that non-pecuniary damages are, as a rule, not compensated by social security (Kun, 2014, p. 67).

As we can see here, the idea behind workers' compensation systems is to find an easier and just way for the employee who has been hurt to reach for compensation. It also seems logical that this system can be beneficial for employers as well, since it - as a rule, provides some kind of certainty when it comes to the costs of work injuries and occupational diseases (due to the immunity rule). Therefore it may seem that this system creates a certain balance of both of their interests - that is both of the interests of the employee and of the employer in question. On the other hand, even though there is no need for proving guilt on the side of the employer, the fact is that benefits provided within the workers' compensation system itself do not fully compensate the loss of the employee. In that sense, it seems to us that this feature of the mentioned system may bring to a certain discontent of the employee in question, and especially if the level of those benefits is not decent. Therefore, even though this approach has its good sides it cannot be said that it is perfect.

\subsection{Employers' liability system}

The key feature of employers' liability schemes is that employees must turn to courts for remedy while, on the other hand, employers can rely on specific grounds for exemption and defence (Kun, 2014, p. 66). In addition to that, another feature of these systems is that the claimant can be entitled to a full compensation of his losses (including damages for pain and suffering) (Wagner, 2012, pp. 12-13), which doesn't change the fact 
that even though this scheme can assure full compensation, court procedures themselves can be costly and time consuming, while their outcome is rather uncertain. With that being said, we also add that they can represent incalculable risks for employers (Kun, 2014, pp. 69-70), while they also pose a threat to social peace, since workplace conflicts tend to be one of the characteristics inherent to civil liability actions (Eengelhard, 2007, p. 17).

The whole idea behind employers' liability is generally based on the fact that employees are obliged to obey their employers while, on the other hand, employers have almost full control over the matters of safety (Kun, 2014, p. 66) - which can be questioned as there is a great deal of individual autonomy at work and accidents don't always occur due to a specific order (Lewis, 2012, p. 142). It should also be noted that the actual satisfaction of claims for damage might not be ensured since the victim bears the risk that the employer might not be solvent or that he might not even exist at the time of judgment (Wagner, 2012, p. 13). So - as we can see, even though this system tends to fully compensate the victim, the possibility still exists that it might fail in that sense.

Anyhow, employers' liability systems may vary from the ones where employers' liability is highly restricted - such as the one applied in Germany (Deinert, 2013, p. 145), the ones where employers' liability plays a big part - such as those applied in the UK and the Netherlands (Wagner, 2012, p. 12) to the extremely rare ones where the employers' liability is an exclusive remedy - such as the system applied in Bangladesh (Klein \& Krohm, 2006, p. 3), or the ones in Kenya and Tanzania (ILO, 2013, p. 5).

\subsection{Shifts from workers' compensation system approach towards a combination of general social security and employers' liability}

Even though in most European states employers' liability is of marginal importance (Parsons, 2002, p. 365), it was revived within the jurisdictions of the UK and the Netherlands, which had abandoned workers' compensation approach (Wagner, 2012, p. 12). Part of the reason for this change of the approach when it comes to the matter of compensation of work injuries and occupational diseases was that the "industrial preference“ "was deemed unwarranted (Wagner, 2012, p. 34). In the UK in 2010/2011, for example, the number of claims that were made in tort was almost twice the number of claims that were made for industrial injuries benefit (Lewis, 2012, p. 186). This, in our opinion, is a clear evidence of the revival of employers' liability when it comes to work injuries and occupational diseases which is why - for better understanding of this phenomenon, a brief presentation of the approach to the matter of compensation of these two risks in the UK and the Netherlands will be made.

In the Netherlands workers' compensation system was introduced in the year of 1901 by the Industrial injuries act, and it was a system that was financed by employers and which was supposed to provide better protection to victims of work injuries. The system itself was based on the risque professionnel approach, while employers enjoyed immunity of civil liability. This approach was abandoned in the year of 1967, mostly due to the aspiration to adequately compensate the non-working disabled. Namely, the standpoint 
that was taken was that it is not decisive how someone got unable to work, but the fact that the person in question was not able to work - which has social consequences (Hoop, 2007, pp. 95-105). Hence, the workers' compensation system which was focused on the so called risque professionnel was replaced by a combination of generous social security benefits and supplementary employers' liability. Unfortunately, this high level of benefits proved to be unsustainable in the long run due to the fact that those benefits were prone to abuses, while the system itself was perceived to be out of control. Therefore, the level of assistance available was gradually lowered (Wagner, 2012, pp. 36-39) And even though social security rules make no difference between accidents at work and the other accidents, some kind of special protection was offered in a way by a rather strict "no fault" oriented regime of tort law liability for damages that were left uncompensated by social security (Engelhard, 2007, p. 10).

In the UK on the other hand, workers' compensation system was established in the year of 1897 through the Workmen's compensation act. The system itself was a no-fault system, which was created outside of tort and was financed by employers. The administration of this scheme was gradually integrated within the general structure of social security - which culminated in abolition of the separate fund for industrial injuries while the funding of the scheme also faced changes and became wholly tax supported. The industrial injuries scheme, which is now a part of general social security provision, is administered by the Department for Work and Pensions, and the claimant has not only the right to claim the industrial injury benefit under this scheme, but also to sue the employer in court (Lewis, 2012, pp. 140, 168, 173). Unlike the employers' liability system, the industrial injuries scheme does not involve fault being established and it can also, in some cases, be the means of support for employees while they pursue the lengthier process of employers' liability claims (Philipsen, 2009, p. 176). Even though a few decades ago there were several different benefits available under industrial scheme nowadays only disablement benefit remains, which is a payment only for non-pecuniary loss, whereas the claimant remains entitled to other benefits under the social security scheme regardless of the cause of ill health. These social security benefits are not very generous, which is partly counterbalanced by the fact that claimants are also being allowed to sue the employer for their work injuries (Lewis, 2012, pp. 162-163). Therefore, since the year of 1972 it became compulsory for the employer to insure against liability to their employees injured in the course of their employment and the failure to comply with this statutory obligation to insure is a subject to sanctions in criminal law (Lewis, 2012, pp. 194-195). The idea behind this employers' liability compulsory insurance was to provide greater security to employers as well as to employees due to the fact that compensation would be available even if the employer becomes insolvent (Philipsen, 2009, p. 176). The introduction of the employers' liability compulsory insurance seems logical as it looks like that, since social security benefits seem to compensate the claimants in small amount, they are to be tempted to sue in court. That being said, we add that the work injury tort claims account for about 78,000 claims a year (Lewis, 2012, p. 140). 
The experience of the United Kingdom and the Netherlands, both of which abandoned workers' compensation for a combination of general social security benefits and employers' liability, has been evaluated as not encouraging enough for the described approach to be considered as recommendable when it comes to this matter. One of the reasons being that generous general social security schemes can be subject of fraud and abuse which is difficult to be controlled (Wagner, 2012, p. 59).

\section{Final remarks}

The importance of protection of employees when it comes to the risk of work injury as well as the risk of occupational disease has not always been considered to be as important as it is nowadays. At the begging these risks were considered to be the risks of the existence itself, while the protection that was provided within the family or via some other form of private assistance, savings, insurance and civil liability had proven to be insufficient. The laissez faire politics of the time didn't help this matter whatsoever, which is why the employees were made extremely vulnerable due to the lack of protective regulations. Significant change to this subject came with the introduction of state managed compulsory insurance at the end of the nineteenth century. Nowadays, the risk of work injury as well as the risk of occupational disease traditionally have preferential treatment comparing to injuries and diseases that are not related to work. Although there are numerous reasons for this kind of treatment of these injuries and diseases, this approach faces some serious critiques and reconsiderations - which is why it was abandoned in some countries in the last few decades. Anyhow - the approach to compensation of work injuries and occupational diseases may vary from the application of the workers' compensation system to the application of employers' liability system, although they usually coexist and supplement each other. The choice between the various systems depends upon the decision of the state in question, although it should be brought to one's attention that the application of the employers' liability system as an exclusive remedy is a choice no European state has gone that far to enforce. What is also noted to be a tendency in some states is the shift from workers' compensation systems as such, to systems which prioritize court procedures, whereas it is an option that has marginal significance in countries with a workers' compensation system in force. On the other hand even in those countries employees are not deprived of all of the social security benefits (whose main purpose is to cover their basic financial needs). Each one of the systems has its advantages and disadvantages. And while workers' compensation system's perceived advantages are their automatic, speedy, transparent and fair results in compensation (the last one being questionable), they can't assure full compensation, whereas the employers' liability system can assure full compensation, but along with the danger of being costly and time consuming, while their outcome is rather uncertain. In addition to that, employers' liability schemes pose a threat to social peace, since workplace conflicts tend to be one of the characteristics inherent to civil liability actions. 
It seems difficult to find the right balance when it comes to this matter - since it is hard to please the interests of employees without being maybe even unfair to employers and vice versa. The conclusion is therefore that, regardless of the approach taken by the state in question, when it comes to the matter compensation of work injuries and occupational diseases, the legislature itself has to make the balance between the interest of the employees for an adequate protection and compensation from the damages caused by work injuries and occupational diseases and the interest of the employers to reduce their costs its main goal. This seems to be one of the elements needed in order for social peace and social justice to be acquired when it comes to this issue.

\section{References}

Deinert, O. 2013. Occupational Health and safety in Germany: a dual system in change. In: Ales, E. (ed.), Health and safety at work - European and comparative perspective. The Netherlands: Kluwer Law International BV, pp. 127-149.

Douka, V. \& Koniaris, V. 2015. Greece. In: Blanpain, R. \& Hendrickx F. (eds.), International Encyclopaedia for Labour Law and Industrial Relations. The Netherlands: Kluwer Law International BV, pp. 1-370.

Engelhard, D. F. E. 2007. Shifts of Work-Related Injury Compensation. Background Analysis: The Concurrence of Compensation Schemes. In: Klosse, S. \& Hartlief, T. (eds.), Shifts in Compensating Work-Related Injuries and Diseases. Wien: Springer Verlag, pp. 9-83.

Glynn, P.T. 2016. United States of America. Alphen aan de Rijn: Kluwer Law International BV. Hendy, J. 2006. The development of employer's liability law. In: Cotter, B. \& Bennett, D. (eds.), Munkman on employer's liability. London: LexisNexis Butterworths, pp. 1-32. Hoop, R. I. R. 2007. Shifts in Work-Related Injuries: An Explanatory Analysis. In: Klosse,

S. \& Hartlief, T. (eds.), Shifts in Compensating Work-Related Injuries and Diseases. Wien: SpringerWienNewYork, pp. 83-159.

ILO, 2013. Strengthening the Role of Employment Injury Schemes to Help Prevent Occupational Accidents and Diseases. Geneva: ILO.

Klein, W. R. \& Krohm, G. 2006. Alternative Approaches to Funding Workers' Compensation. Atlanta: Georgia State University.

Kovačević, Lj. 2007. Normiranje socijalne sigurnosti u međunarodnom pravu. Magistarska teza. Beograd: Pravni fakultet Univerziteta u Beogradu.

Kremalis, K. 2015. Social security law in Greece. The Netherlands: Kluwer Law International. Lewis, R. 2012. Employers' Liability and Workers' Compensation: England and Wales. In: Oliphant, K. \& Wagner, G. (eds.), Employers' liability and workers' compensation. Germany: De Gruyter, pp. 137-203.

Lubarda, B. 2013. Uvod u radno pravo. Beograd: Pravni fakultet Univerziteta u Beogradu. Parsons, S. 2002. Liability Rules, Compensation Systems and Safety at Work in Europe. The Geneva Papers on Risk and Insurance, 27(3), pp. 358-382. 
Philipsen, S. N. 2019. Compensation for industrial accidents and incentives for prevention: A theoretical and empirical perspective. European Journal of Law and Economics, 28, pp. 163-183.

Ravnić, A. 2004. Osnove radnog prava-domaćeg, usporednog i medunarodnog. Zagreb: Sveučilište u Zagrebu - Pravni fakultet.

Wagner, G. 2012. Tort, social security, and no-fault schemes: lessons from real-world experiments. Duke Journal of Comparative \& International Law, 23(1), pp. 1-61.

\section{Legal sources}

Labour Law, 2005. Official Gazette, nr. 24/2005, 61/2005, 54/2009, 32/2013, 75/2014, $13 / 2017$ - ruling CC, 113/2017 and 95/2018 - authentic interpretation.

Law of Contracts and Torts, 1978. Official Gazette of the SFR of Yugoslavia nr. 29/1978; Amendments in nrs.: 39/1985, 45/1989, and 57/1989; final amendments in the Official Gazette of the FR of Yugoslavia nr. 31/1993.

Law on Contributions for Compulsory Social Insurance, 2004. Official Gazette, nr. 84/2004, 61/2005, 62/2006, 5/2009, 52/2011, 101/2011, 7/2012 - adjusted din. amount, 8/2013 - adjusted din. amount., 47/2013, 108/2013, 6/2014 - adjusted din. amount., 57/2014, 68/2014 - adjusted din. amount, 5/2015 - adjusted din. amount, 112/2015, 5/2016 - adjusted din. amount., 7/2017 - adjusted din. amount., 113/2017, 7/2018 - adjusted din. amount. and 95/2018.

\section{Internet sources}

Dontas, S. 2017. OSH system at national level - Greece. Available at: https://oshwiki.eu/ wiki/OSH_system_at_national_level_-_Greece, (30.10.2019).

Kun, A. 2014. Work accident compensation in Hungarian labour law - liability rules and compensation. Hungarian labour lawe - journal, 1, pp. 64-81, Available at: http:// hllj.hu/letolt/2014_1_a/04.pdf, (20.4.2019).

MISSOC database.n.d. Available at: https://www.missoc.org/missoc-database/comparativetables/results/, (29.10.2019). 


\title{
Mila D. Petrović, master
}

Doktorand, Pravni fakultet, Univerzitet u Beogradu, Srbija

e-mail: mila.petrovic89@gmail.com

\section{ODŠTETA POVREDA NA RADU I PROFESIONALNIH BOLESTI - KOMPARATIVNI PRISTUP}

\author{
Sažetak
}

Značaju zaštite zaposlenih kada je reč o rizicima povrede na radu i profesionalne bolesti nije oduvek bila pridavana pažnja kao danas. Na početku ovi rizici su smatrani rizicima samog postojanja dok danas oni, već tradicionalno, imaju preferencijalni tretman u odnosu na povrede i bolesti koje nisu nastale u vezi sa radom. I iako postoje mnogobrojni razlozi za ovakav pristup on trpi i ozbiljne kritike - te je stoga i napušten u nekim zemljama. Bilo kako bilo - sam pristup pitanju odštete povreda na radu i profesionalnih bolesti može ići od primene sistema odštete zaposlenih, pa do sistema odgovornosti poslodavca $z a$ odštetu zaposlenih, mada oni po pravilu postoje istovremeno i dopunjuju jedno drugo. Izbor u pogledu toga koji će se od pomenutih sistema primenjivati zavisi od države u pitanju, mada treba imati u vidu da primena sistema odgovornosti poslodavca za odštetu zaposlenih kao jedinog "leka" jeste rešenje kojem ni jedna evropska država nije pribegla, iako je u nekim državama primećena tendencija napuštanja sistema odštete zaposlenih, uz davanje prioriteta sudskoj proceduri.

Kako se radi o tematici koja je značajna i za zaposlene i za poslodavce, ovo istraživanje obavljeno je sa ciljem da se napravi pregled različitih sistema odštete, kao i da se stvori ideja o njihovim osobinama. S tim u vezi, zaključak do kog se dolazi jeste da, bez obzira na pristup za koji se država u pitanju odluči kada govorimo o odšteti zaposlenih za povrede na radu i profesionalne bolesti, zakonodavac mora težiti rešenju kojim će se postići ravnoteža interesa zaposlenih za adekvatnom odštetom, kao i interesa poslodavaca da umanje svoje troškove. Ovo se čini neophodnim kako bi se postigli socijalni mir i socijalna pravda u pogledu ove problematike.

Ključne reči: povreda na radu, profesionalna bolest, odšteta, sistem odštete zaposlenih, sistem odgovornosti poslodavca za odštetu zaposlenih.

Article history:

Received: 14 November 2019

Accepted: 27 January 2020 